ISSN : 2615-1995, E-ISSN : 2615-0654

J. Madani., Vol. 4, No. 1, Maret 2021 (61 - 69)

(C)2018 Lembaga Kajian Demokrasi

\title{
Pengaruh Return on Asset dan Non Performing Loan Terhadap Capital Adequacy Ratio Pada PT Bank Mega Tbk
}

\author{
Faisal \\ Fakultas Ekonomi, Universitas Pamulang \\ dosen00414@unpam.ac.id
}

\begin{abstract}
Abstrak
Penelitian ini bertujuan untuk mengetahui pengaruh antara variabel independen terhadap variabel dependen. Variabel independen yang digunakan dalam penelitian ini adalah Return on Asset, Non Performing Loan. Sedangkan variabel dependen dalam penelitian ini adalah Capital Adequacy Ratio. Data yang digunakan dalam penelitian ini adalah data kuartal selama periode 2010 sampai dengan 2018. Teknik sampling yang digunakan dalam penelitian ini adalah purposive sampling yang melibatkan Bank Mega Tbk. Teknik analisis yang digunakan adalah analisis regresi linear berganda. Berdasarkan hasil analisis data penelitian ini menunjukan secara bersama-sama (Simultan) Return on Asset, Non Performing Loan berpengaruh signifikan terhadap Capital Adequacy Ratio. Dan secara individu (Parsial) Net Interest Margin, Non Performing Loan dan Return on Asset berpengaruh positif terhadap CAR, berpengaruh negatif terhadap CAR. Hasil Koefisien Determinasi menunjukan nilai Adjusted R-squared sebesar 0,714240 artinya bahwa variabel independen dapat menjelaskan variabel dependen sebesar 71,42\% sedangkan sisanya dijelaskan oleh variabel lain yang tidak terdapat dalam model. Dalam penelitian ini permaslahan yang peneliti ingin ketahui adalah apakah ada hubungan yang signifikan antara Return on Asset, Non Performing Loan berpengaruh signifikan terhadap Capital Adequacy Ratio
\end{abstract}

Kata Kunci : Return on Asset, Non Performing Loan, Capital Adequacy Ratio.

\begin{abstract}
This study aims to determine the effect of the independent variables on the dependent variable. The independent variable used in this study is Return on Assets, Non Performing Loans. While the dependent variable in this study is the Capital Adequacy Ratio. The data used in this study are quarterly data from 2010 to 2018. The sampling technique used in this study was purposive sampling involving Bank Mega Tbk. The analysis technique used is multiple linear regression analysis. Based on the results of data analysis, this study shows that simultaneously (Simultaneous) Return on Assets, Non Performing Loans have a significant effect on Capital Adequacy Ratio. And individually (partial) Net Interest Margin, Non Performing Loans and Return on Assets have a positive effect on CAR, negatively affect CAR. Determination coefficient results indicate the Adjusted $R$-squared value of 0.714240 means that the independent variable can explain
\end{abstract}


the dependent variable by $71.42 \%$ while the rest is explained by other variables not contained in the model. In this study, the researcher wanted to find out whether there was a significant relationship between Return on Assets, Non-Performing Loans had a significant effect on the Capital Adequacy Ratio.

Keywords : Return on Assets, Non Performing Loans, Capital Adequacy Ratio

\section{PENDAHULUAN}

Bank merupakan nyawa dalam menggerakkan perekonomian. Bank Mega Tbk merupakan lembaga keuangan yang kegiatannya menghimpun dana dari masyarakat dalam bentuk simpanan dan menyalurkannya ke masyarakat dalam bentuk kredit atau bentuk-bentuk lainnya dalam rangka meningkatkan tarap hidup rakyat banyak. Kinerja bank dapat diamati dari rasio Capital Adequacy Rasio. Adapun Capital Adequacy Rasio adalah rasio yang memperlihatkan seberapa jauh seluruh aktiva bank yang mengandung risiko (kredit, penyertaan, surat berharga, tagihan pada bank lain) ikut di biayai dari dana modal sendiri bank disamping memperoleh dana dana dari sumbersumber di luar bank, seperti dana masyarakat, pinjaman (hutang), dan lain-lain.

Return on Asset memfokuskan kemampuan perusahaan untuk memperoleh Earning/dalam operasi perusahaan. Hubungan antara Return on Asset terhadap Capital Adequacy Rasio suatu bank adalah positif, dimana jika Return on Asset suatu bank meningkat maka Capital Adequacy Rasio akan meningkat juga. Jadi apabila Return on Asset terus meningkat maka modal bank tersebut akan terus bertambah dan dapat digunakan untuk kegiatan operasional yang akan menghasilkan laba atau keuntungan. Pemberian kredit yang dilakukan oleh bank mengandung resiko yaitu tidak lancarnya pembayaran kembali kredit atau dengan kata lain disebut kredit bermasalah (Non Perfoming Loan) sehingga akan mempengaruhi kinerja bank.

Kredit bermasalah yang terjadi pada bank tersebut dapat diturunkan dengan cara ekspansi atau restrukturisasi. Upaya menghindari resiko kerugian karena kualitas kredit yang semakin memburuk pemerintah harus merestrukturisasi kredit perbankan hubungan antara Non Perfoming Loan terhadap Capital Adequacy Rasio suatu bank adalah negative, dimana jika Non Perfoming Loan suatu bank meningkat maka Capital Adequacy Rasio akan menurun. Sebaliknya jika Non Perfoming Loan suatu bank menurun maka Capital Adequacy Rasio akan meningkat.
Tabel 1. Perhitungan CAR, NPL, dan ROA pada PT Bank Mega Tbk. Periode 2008-2018

\begin{tabular}{cccc}
\hline Tahun & ROA (\%) & $\begin{array}{c}\text { Variabel } \\
\text { NPL (\%) }\end{array}$ & CAR (\%) \\
\hline 2008 & 1,98 & 0,79 & 16,09 \\
2009 & 1,77 & 1,02 & 18,01 \\
2010 & 2,45 & 0,74 & 15,03 \\
2011 & 2,29 & 0,71 & 11,86 \\
2012 & 2,74 & 1,30 & 16,83 \\
2013 & 1,14 & 1,64 & 15,74 \\
2014 & 1,16 & 1,34 & 15,23 \\
2015 & 1,97 & 1,80 & 22,85 \\
2016 & 2,36 & 2,59 & 26,21 \\
2017 & 2,08 & 2,01 & 24,11 \\
2018 & 2,07 & 2,28 & 22,79 \\
\hline
\end{tabular}

Sumber Data: PT. Bank Mega Tbk

Berdasarkan tabel di atas Return on Asset pada PT Bank Mega tbk. Mengalami fluktuasi setiap tahunnya. Pada 2010 terjadi kenaikan Return on Asset diikuti dengan penurunan Capital Adequacy Rasio. Hal ini bertentangan dengan hubungan yang berlaku antara Return on Asset dengan Capital Adequacy Rasio di mana apabila Return on Asset meningkat maka Capital Adequacy Rasio akan meningkat juga.

Non Perfoming Loan pada PT Bank Mega Tbk. mengalami fluktuasi setiap tahunnya. Pada 2010 terjadi penurunan Non Performing Loan diikuti dengan penurunan Capital Adequacy Rasio. Hal ini bertentangan dengan hubungan yang berlaku antara Non Performing Loan dengan Capital Adequacy Rasio di mana apabila Non Performing Loan menurun maka Capital Adequacy Rasio akan meningkat. Return on Asset pada Bank Mega Tbk periode 2010 - 2018 mengalami flukuatif setiap tahunnya. Pada 2011 mengalami penurunan pada Return on Asset dan mengalami kenaikan pada Capital Adequacy Rasio pada 2015. Sedangkan Return on Asset pada 2015 sampai dengan 2016 mengalami kenaikan dan Non Performing Loan pada 2011 sampai dengan 2015 mengalami kenaikan yang terus-menerus. 


\section{METODE}

\section{Metode Penelitian}

Metode yang digunakan dalam penelitian ini adalah kuantitatif. Menurut Sugiyono (2017:8), penelitian kuantitatif adalah metode penelitian yang berlandaskan pada filsafat positivisme, digunakan untuk meneliti pada populasi atau sampel tertentu, pengumpulan data menggunakan instrumen penelitian, dan analisis data bersifat kuantitatif atau statistik, dengan tujuan untuk menguji hipotesis yang telah ditetapkan. Sehingga judul yang diambil: "Pengaruh Return on Asset dan Non Perfoming Loan terhadap Capital Adequacy Rasio pada PT Bank Mega Tbk, Periode 2010 - 2018".

Analisis data pada penelitian ini menggunakan metode analisis regresi linier. Dalam penelitian ini penulis menggunakan alat analisis SPSS dan Microsoft Excel sebagai bantuan dalam melakukan analisis data.

\section{Tempat Penelitian}

Menurut Sugiyono (2017:13), tempat penelitian adalah sasaran ilmiah untuk mendapatkan data dengan tujuan dan kegunaan tertentu tentang sesuatu hal yang objektif. Penelitian ini dilakukan di Bank Mega Tbk Karet Kuningan, Jakarta Selatan.

\section{Operasional Variabel Penelitian}

Operasional variabel menurut Sugiyono (2017:63) adalah suatu atribut atau sifat atau nilai dari orang objek atau kegiatan yang mempunyai variasi yang tertentu yang diterapkan oleh peneliti untuk dipelajari dan kemudian ditarik kesimpulannya. Operasional variabel diperlukan dalam menentukan jenis, indikator, dan skala dari variabel-variabel yang terkait dalam suatu penelitian. Dengan demikian pengujian hipotesis dengan alat bantu statistik dapat dilakukan secara benar.

\section{Metode Pengumpulan Data \\ Dokumentasi}

Menurut Sugiyono (2017:138), dokumen merupakan catatan peristiwa yang sudah berlalu. Dokumen bisa berbentuk tulisan atau gambar. Metode ini digunakan untuk memperoleh data tentang sejarah perusahaan, jumlah karyawan, dan sebagainya. Dalam penelitian ini peneliti menggunakan data yang bersumber dari laporan keuangan Bank Mega Tbk yang terdapat dalam IDX ( Indonesia Stock exchange) periode 2010 - 2018.

\section{Studi Kepustakaan}

Menurut Sugiyono (2017:140), studi kepustakaan berkaitan dengan kajian teoritis dan referensi lain yang berkaitan dengan nilai, budaya dan norma yang diteliti dan penting dalam melakukan penelitian. Hal ini dikarenakan penelitian tidak akan lepas dari literatur ilmiah. Dalam penelitian ini studi kepustakaan dilakukan dengan mencari landasan teoritis yang berhubungan dengan judul penelitian.

\section{Uji Instrumen Data}

\section{Uji Validitas}

Valid adalah menunjukkan derajat ketepatan antara data yang sesungguhnya terjadi pada obyek dengan data yang dapat dikumpulkan oleh peneliti. Menurut Sugiyono (2017:361), valid berarti terdapat kesamaan antara data yang terkumpul dengan data yang sesungguhnya. Menurut Ghozali (2017:52), suatu kuesioner dikatakan valid jika pertanyaan pada kuesioner mampu untuk mengungkapkan sesuatu yang akan diukur oleh kuesioner tersebut. Untuk melakukan uji validitas dilihat dari tabel Item-Total Statistics. Nilai tersebut dibandingkan dengan nilai $r$ hitung $>\mathrm{r}$ tabel atau dapat juga dengan nilai chronbach alpha $>$ standar kritis alpha, maka dikatakan valid. Untuk menguji validitas setiap instrumen, menurut Sugiyono (2017:356), rumus yang digunakan adalah koefisien korelasi Product Moment sebagai berikut:

$$
r x y=\frac{\mathrm{n}\left(\sum \mathrm{xy}\right)-\left(\sum x\right)\left(\sum y\right)}{\sqrt{\left\{n \cdot \sum x^{2}-\left(\sum x\right)^{2}\right\}\left\{n \cdot \sum y^{2}-\left(\sum y\right)^{2}\right\}}}
$$

Keterangan:

Rxy $=$ koefisien korelasi antar X dan Y

$\mathrm{N} \quad=$ jumlah responden

$\mathrm{X}=$ skor item kuesioner

$\mathrm{Y}=$ total skor item kuesioner

$\sum \mathrm{X}^{2}=$ jumlah kuadrat seluruh skor $\mathrm{X}$

$\sum \mathrm{y}^{2}=$ jumlah kuadrat seluruh skor $\mathrm{Y}$

Kriteria atau syarat keputusan suatu instrumen dikatakan valid dan tidaknya menurut Sugiyono (2017:173) yaitu dengan membandingkan antara nilai r-hitung dengan r-tabel dengan ketentuan sebagai berikut: 
1. Jika r-hitung $>$ r-tabel, maka instrumen dikatakan valid.

2. Jika r-hitung $<$ r-tabel, maka instrumen dikatakan tidak valid.

\section{Uji Reliabilitas}

Menurut Sugiyono (2017:168), instrumen yang reliabel jika digunakan beberapa kali untuk mengukur obyek yang sama, akan menghasilkan data yang sama. Sedangkan menurut Ghozali (2017:47), reliabilitas merupakan alat untuk menguji kekonsistenan jawaban responden atas pernyataan di kuesioner. Suatu kuesioner dikatakan reliabel jika jawaban seseorang terhadap pernyataan adalah konsisten atau stabil dari waktu ke waktu.

Rumus yang digunakan pada penelitian ini reliabilitas dicari dengan menggunakan rumus alpha atau cronbach's alpha $(\alpha)$ dikarenakan instrumen pertanyaan kuesioner yang dipakai merupakan rentangan antara beberapa nilai dalam hal ini menggunakan skala rating 1 sampai dengan 5. Menurut Suharsimi Arikunto (2015:223) cara menghitung tingkat reliabilitas suatu data yaitu dengan menggunakan rumus Alpha Cronbach sebagai berikut:

$$
r_{11}=\left[\frac{k}{k-1}\right]\left[1-\frac{\sum{\sigma_{b}}^{2}}{\sigma_{1}^{2}}\right]
$$

\section{Keterangan:}

r11 = Koefisien reliabilitas

$\mathrm{k}=$ Jumlah butir pertanyaan

$\sum \sigma_{b}^{2}=$ Jumlah variansi butir pertanyaan

$\sigma_{1}^{2} \quad=$ variansi total

Dalam penelitian ini, pengukuran yang dipakai adalah dengan membandingkan nilai Cronbach's Alpha dengan 0,60, di mana menurut Ghozali (2017:238) dapat berpedoman sebagai berikut:

1. Jika Nilai Cronbach's Alpha $>0,60$, maka instrumen reliabel.

2. Jika Nilai Cronbach's Alpha $<0,60$, maka instrumen tidak reliabel

\section{Uji Asumsi Klasik}

\section{Uji Normalitas}

Menurut Ghozali (2017:160), model regresi yang baik adalah berdistribusi normal atau mendekati normal. Jadi uji normalitas bukan dilakukan pada masing-masing variabel tetapi pada nilai residualnya. Dengan demikian uji ini untuk memeriksa apakah data yang berasal dari populasi terdistribusi normal atau tidak. Data yang baik dan layak untuk membuktikan model-model penelitian tersebut adalah data yang berdistribusi normal. Uji Normalitas yang digunakan yakni:

Metode Uji One Sample Kolmogorov Smirnov

Menurut Sugiyono (2017:257), uji normalitas dapat diuji dengan Kolmogorov Smirnov dengan rumus:

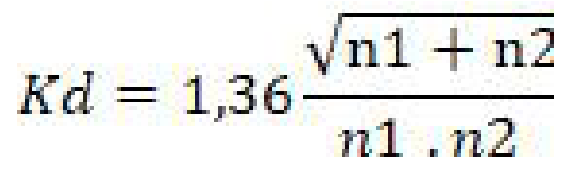

Keterangan:

KD : Jumlah Kolmogorov-Smirnov yang dicari

n1 : Jumlah sampel yang diperoleh

n2 : Jumlah sampel yang diharapkan

\section{Metode Grafik}

Uji normalitas juga dapat dideteksi dengan melihat penyebaran pada (titik) pada sumbu diagonal pada grafik Probability Plot. Adapun menurut Ghozali (2017:164), dasar pengambilan keputusan sebagai berikut:

a. Jika data menyebar disekitar garis diagonal dan mengikuti arah garis diagonal, maka model regresi memenuhi normalitas.

b. Jika data menyebar jauh dari garis diagonal dan tidak mengikuti arah garis diagonal, maka model regresi tidak memenuhi normalitas.

\section{Uji Multikolinieritas}

Uji Multikolinieritas ini bertujuan menguji apakah pada model regresi ditemukan adanya korelasi antar variabel independen. Menurut Ghozali (2017:105), uji multikolineritas bertujuan untuk menguji apakah pada model regresi ditemukan adanya korelasi antar variabel bebas (independen). Model regresi yang baik seharusnya tidak terjadi korelasi di antara variabel independen. Jika variabel independen saling berkorelasi, maka variabel-variabel ini tidak ortogonal. Variabel ortogonal adalah variabel independen yang nilai korelasi antar sesama variabel independen sama dengan nol.

Menurut Singgih Santoso (2015:234), jika terbukti ada multikolinieritas, sebaiknya salah satu dari variabel independen yang ada dikeluarkan dari model, lalu pembuatan model regresi diulang kembali. Adapun untuk mendeteksi ada tidaknya 
multikoliniearitas dalam model regresi dapat dilihat dari tolerance value atau Variance Inflation Factor (VIF) dengan rumus sebagai berikut:

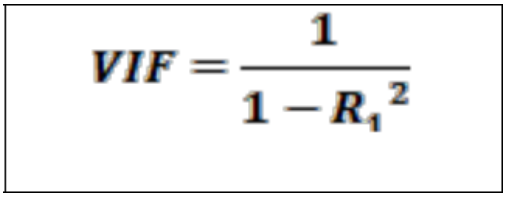

Dalam penelitian ini ketentuan untuk mendeteksi ada atau tidaknya multikolonieritas di dalam model regresi dapat dilihat dari nilai tolerance dan lawannya, variance inflation factor (VIF). Kedua ukuran ini menunjukkan setiap variabel independen manakala yang dijelaskan oleh variabel independen lainnya. Tolerance mengukur variabilitas variabel independen yang terpilih yang tidak dijelaskan oleh variabel independen lainnya. Jadi nilai tolerance yang rendah sama dengan nilai VIF tinggi (karena VIF $=1 /$ Tolerance . . Model Regresi yang baik adalah yang tidak terjadi multikolinieritas.

\section{Uji Autokorelasi}

Uji autokorelasi digunakan untuk mengetahui ada atau tidaknya penyimpangan asumsi klasik autokorelasi, yaitu adanya korelasi antar anggota sampel. Menurut Ghozali (2017:110), uji autokorelasi bertujuan menguji apakah dalam model regresi liner ada korelasi antar kesalahan pengganggu pada periode $t$ dengan kesalahan pengganggu pada periode $\mathrm{t}-1$. Model regresi yang baik adalah regresi yang bebas dari autokorelasi. Cara yang dapat digunakan untuk menditeksi ada atau tidaknya autokorelasi dalam penelitian ini yaitu dengan uji Durbin-Watson (DW test), di mana menurut Singgih Santoso (2015:234) menggunakan rumus:

$$
d=\frac{\sum_{t}^{n}=2\left(e_{t}=e_{t}-1\right)^{2}}{\sum_{t}^{n}={ }_{1} e^{2} t}
$$

\section{Keterangan}

et : adalah residual tahun $\mathrm{t}$

et-1 : adalah residual satu tahun sebelumnya

Menurut Algifari (2014:88), konsekuensi dari adanya autokorelasi dalam suatu model regresi adalah varian sampel tidak dapat menjelaskan varian populasinya. Dalam pengujian ini, digunakan sofware SPSS versi 26. Selanjutnya untuk mengetahui ada tidaknya autokorelasi dilakukan uji Durbin-Watson.
Tabel 2. Autokorelasi

\begin{tabular}{cc}
\hline Kriteria & Keterangan \\
\hline$<1,000$ & Ada autokorelasi \\
$1,100-1,550$ & Tanpa kesimpulan \\
$1,550-2,460$ & Tidak ada autokorelasi \\
$2,460-2,900$ & Tanpa kesimpulan \\
$>2,900$ & Ada autokorelasi \\
\hline
\end{tabular}

Sumber: Singgih Santoso (2015)

\section{Analisis Koefisien Determinasi}

Analisis koefisien determinasi dimaksudkan untuk mengetahui besarnya pengaruh antara variabel independen terhadap variabel dependen baik secara parsial maupun simultan. Menurut Andi Supangat (2015:350), koefisien determinasi merupakan besaran untuk menunjukkan tingkat kekuatan hubungan antara dua variabel atau lebih dalam bentuk persen. Berdasarkan dari pengertian ini maka koefisien determinasi merupakan bagian dari keragaman total dari variabel terikat yang dapat diperhitungkan oleh keragaman variabel bebas dihitung dengan koefisien determinasi dengan asumsi dasar faktor-faktor lain di luar variabel dianggap konstan.

Rumus yang digunakan dalam analisis ini menurut Sugiyono (2017:350) untuk mengetahui besarnya kontribusi dari variabel bebas terhadap variabel terikat yang dapat dihitung suatu koefisien yang disebut koefisien penentuan, yang dirumuskan sebagai berikut:

$$
\mathrm{KD}=\mathrm{r} 2 \times 100 \%
$$

Keterangan:

KD : Koefisien Determinasi

$\mathrm{r} \quad$ : Koefisien Korelasi antara variabel bebas dan terikat (yang dikuadratkan)

100\%: Pengalian yang dipresentasikan

Dalam pengujian ini, digunakan sofware SPSS versi 26. Adapun ketentuan besarnya nilai koefisien determinasi $(\mathrm{Kd})$ antara 0 (nol) sampai dengan 1 (satu) dimana interpretasinya adalah:

a. Jika determinasi bernilai $0=$ berarti tidak ada hubungan antara variabel X1 dan X2 (bebas) dengan variabel $\mathrm{Y}$ (terikat).

b. Jika determinasi bernilai $1=$ berarti ada kecocokan yang sempurna dari ketepatan perkiraan model. 


\section{Pengujian Hipotesis}

\section{Uji Hipotesis Secara Parsial (Uji t)}

Uji t atau uji parsial dimaksudkan untuk menguji bagaimana pengaruh masing-masing variabel bebasnya secara sendiri-sendiri terhadap variabel terikatnya. Rumus yang digunakan dalam pengujian hipotesis (uji t) ini, menurut Sugiyono (2017:184) dapat menggunakan dengan mencari nilai t hitung dengan rumus sebagai berikut:

$$
t=\frac{r_{1} \sqrt{\mathrm{n}-2}}{\sqrt{\left(1-r_{1}^{2}\right)}}
$$

\section{Keterangan:}

$\mathrm{t}=$ Probabilitas

$\mathrm{r} \quad$ Koefisien korelasi parsial

$\mathrm{n}=$ Jumlah sampel.

Taraf signifikansi yang digunakan $\alpha=0,05$ $(5 \%)$ artinya kemungkinan hasil penarikan kesimpulan mempunyai probabilitas $95 \%$. Kriteria hipotesis diterima atau ditolak yaitu dengan membandingkan antara nilai $t$ hitung dengan $t$ tabel dengan kriteria sebagai berikut:

a. Jika nilai $t$ hitung $>\mathrm{t}$ tabel, maka HO ditolak dan Ha diterima.

b. Jika nilai $t$ hitung $>\mathrm{t}$ tabel, maka $\mathrm{H} 0$ diterima dan Ha ditolak.

\section{Uji Hipotesis Secara Simultan (Uji F)}

Uji $F$ atau simultan dimaksudkan untuk menguji pengaruh semua variabel bebas secara simultan terhadap variabel terikat. Rumus yang digunakan menurut Sugiyono (2017:252) untuk mengetahui pengaruh secara simultan (bersamasama) antara variabel independen terhadap variabel dependen". Untuk mencari nilai F hitung digunakan rumus sebagai berikut:

$$
F_{\text {hitung }}=\frac{r^{2} / \mathrm{k}}{\left(1-r^{2}\right) /(n-k-1)}
$$

\section{Keterangan:}

r2 = Koefisien korelasi ganda

$\mathrm{k}=$ Jumlah variabel independen

$\mathrm{n}=$ Jumlah data (sampel responden)

Kriteria hipotesis diterima atau ditolak yaitu dengan mebandingkan antara nilai $\mathrm{F}$ hitung dengan $\mathrm{F}$ tabel dengan kriteria sebagai berikut:

a. Jika nilai F hitung $>$ F tabel, maka H0 ditolak dan Ha diterima. b. Jika nilai $\mathrm{F}$ hitung $<\mathrm{F}$ tabel, maka $\mathrm{H} 0$ diterima dan Ha ditolak.

Kriteria dikatakan signifikan jika nilai $\mathrm{F}$ hitung $>$ F tabel atau probability signifikansi $<0,05$.

\section{HASIL}

\section{Uji Asumsi Klasik}

\section{Uji Normalitas}

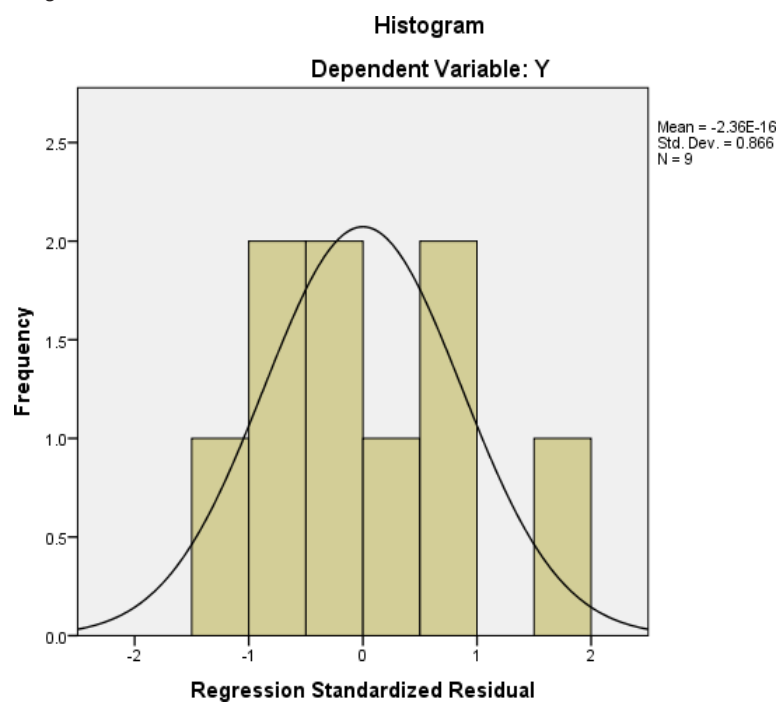

Gambar 1. Hasil Uji Histogram Normalitas

(Sumber: Data diolah)

Normal P-P Plot of Regression Standardized Residual

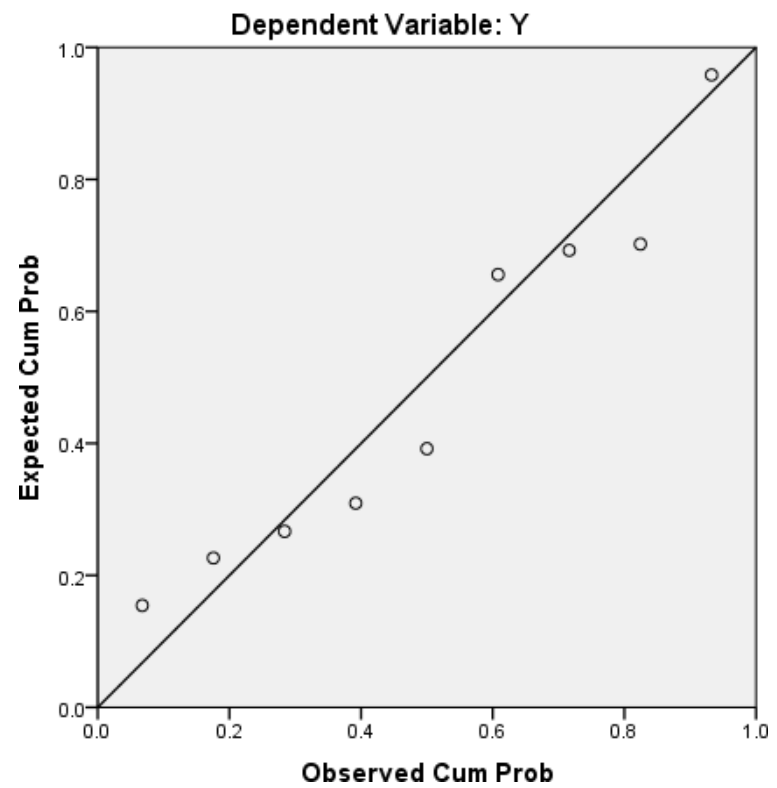

Gambar 2. Hasil Uji P-P Plot Normalita

(Sumber: Data diolah) 


\section{Uji Multikolinearitas}

Tabel 3. Hasil Uji Multikolineritas

\begin{tabular}{|c|c|c|c|c|c|c|c|c|}
\hline & \multirow[b]{2}{*}{ Model } & \multicolumn{2}{|c|}{$\begin{array}{c}\text { Unstandardized Coef- } \\
\text { ficients }\end{array}$} & \multirow{2}{*}{$\begin{array}{c}\text { Standar } \\
\text { dized } \\
\text { Coeffici ents } \\
\text { Beta }\end{array}$} & \multirow[t]{2}{*}{$\mathbf{t}$} & \multirow[t]{2}{*}{ Sig. } & \multicolumn{2}{|c|}{ Collinearity Statistics } \\
\hline & & B & Std. Error & & & & Tolerance & VIF \\
\hline & (Constant) & 317.018 & 528.960 & & .599 & .571 & & \\
\hline \multirow[t]{2}{*}{1} & ROA & 3.072 & 1.902 & .365 & 1.615 & .157 & .969 & 1.032 \\
\hline & NPL & 4.920 & 1.350 & .822 & 3.644 & .011 & .969 & 1.032 \\
\hline
\end{tabular}

Dependent Variable: CAR

Sumber: Data diolah

\section{Uji Autokolerasi}

Tabel 4. Uji Autokolerasi

Model Summary

\begin{tabular}{cccccc}
\hline Model & R & R Square & Adjusted R Square & Std. Error of the Estimate & Durbin-Watson \\
\hline 1 & $.914^{\mathrm{a}}$ & .836 & .781 & 284.21296 & 2.858 \\
\hline
\end{tabular}

a. Predictors: (Constant), NPL, ROA

b. Dependent Variable: CAR

Sumber: Data diolah

\section{Uji Heteroskedastisitas}

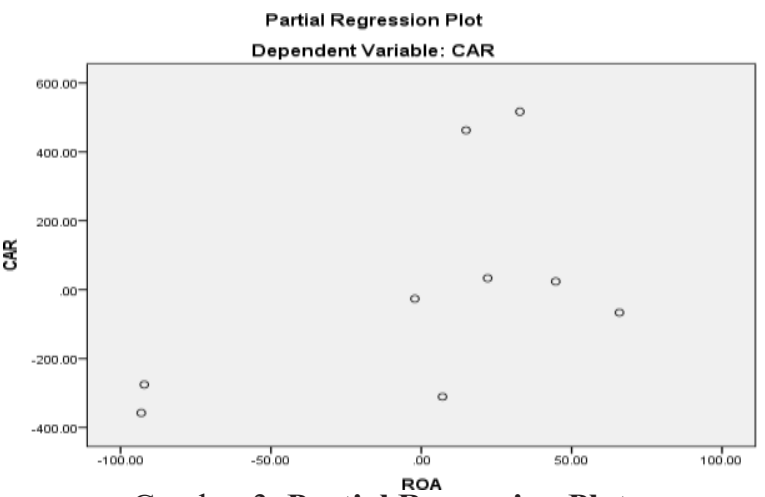

Gambar 3. Partial Regression Plot

Sumber: Data diolah
Dari tabel data yang diperoleh dapat disusun persamaan regresi linier berganda sebagai berikut:

$$
Y=-1240.910+3.924 X 1+15.049 X 2
$$

Persamaan regresi diatas mempunyai arti sebagai berikut:

\section{Koefisien Konstanta Sebesar $\mathbf{- 1 2 4 0 . 9 1 0}$}

Menyatakan bahwa jika variabel bebas dianggap konstanta karena memiliki nilai negatif, maka pengaruh yang kurang baik untuk tingkat pengembalian asset perusahaan dari melakukan investasi.

\section{Regrensi Linear Berganda}

Tabel 5. Hasil Uji Coefficients

Coefficients $^{\mathrm{a}}$

\begin{tabular}{|c|c|c|c|c|c|}
\hline \multirow{2}{*}{ Model } & \multicolumn{2}{|c|}{ Unstandardized Coefficients } & \multirow{2}{*}{$\begin{array}{c}\text { Standardized Coefficients } \\
\text { Beta }\end{array}$} & \multirow{2}{*}{$\mathbf{t}$} & \multirow{2}{*}{ Sig. } \\
\hline & B & Std. Error & & & \\
\hline (Constant) & -1240.910 & 570.949 & & -2.173 & .073 \\
\hline 1. $\mathrm{ROA}$ & 3.924 & 1.849 & .351 & 2.122 & .078 \\
\hline NPL & 15.049 & 2.975 & .837 & 5.058 & .002 \\
\hline
\end{tabular}

Dependent Variable: CAR

Sumber: Data diolah 


\section{Variabel Return On Asset (X1) Sebesar 3.924X1}

Variabel Return on Asset bernlai positif hal ini berarti terjadi hubungan positif antara Return on Asset dengan Capital Adequacy Ratio, semakin naik Return on Asset maka semakin Capital Adequacy Ratio.

\section{Variabel Non Performing Loan (X2) Sebesar 15.049X2}

Variabel Non Performing Loan bernlai positif hal ini berarti terjadi hubungan positif antar Non Performing Loan dengan Capital Adequacy Ratio, semakin naik Non Performing Loan maka semakin naik Capital Adequacy Ratio.

\section{Uji Hipotesis}

Uji parsial (Uji F)

\section{Tabel 6. Hasil Uji F}

ANOVA $^{\mathrm{a}}$

\begin{tabular}{lccccc}
\hline \multicolumn{1}{c}{ Model } & $\begin{array}{c}\text { Sum of } \\
\text { Squares }\end{array}$ & df & $\begin{array}{c}\text { Mean } \\
\text { Square }\end{array}$ & F & Sig. \\
\hline $\begin{array}{l}\text { Regres- } \\
\text { sion }\end{array}$ & 2469720.855 & 2 & 1234860.428 & 15.287 & $.004^{\mathrm{b}}$ \\
Residual & 484662.034 & 6 & 80777.006 & & \\
Total & 2954382.889 & 8 & & & \\
\hline
\end{tabular}

a. Dependent Variable: CAR

b. Predictors: (Constant), ROA, NPL

Sumber: Data diolah

Dari uji Anova (Analysis of Varians) pada tabel 4.9 Dapat dilihat F sebesar 15.287 dengan nilai signfikan sebesar 0.004 Dengan demikian dapat dikatakan bahwa Return on Asset dan Non Performing Loan secara bersama-sama berpengaruh signifikan terhadap Capital Adequacy Ratio.

\section{Uji Parsial (Uji t)}

Tabel 7. Hasil Uji t

Coefficients $^{\mathrm{a}}$

\begin{tabular}{|c|c|c|c|c|c|}
\hline \multirow{2}{*}{ Model } & \multicolumn{2}{|c|}{$\begin{array}{l}\text { Unstandardized } \\
\text { Coefficients }\end{array}$} & \multirow{2}{*}{$\begin{array}{c}\text { Standardi zed } \\
\text { Coefficients } \\
\text { Beta }\end{array}$} & \multirow{2}{*}{$\mathbf{t}$} & \multirow{2}{*}{ Sig. } \\
\hline & B & $\begin{array}{l}\text { Std. Er- } \\
\text { ror }\end{array}$ & & & \\
\hline $\begin{array}{l}\text { (Con- } \\
\text { stant) }\end{array}$ & $-\overline{1240.910}$ & 570.949 & & -2.173 & .073 \\
\hline ROA & 3.924 & 1.849 & .351 & 2.122 & .078 \\
\hline NPL & 15.049 & 2.975 & .837 & 5.058 & .002 \\
\hline
\end{tabular}

Dependent Variable: CAR

Sumber: Data diolah

Hasil uji t antara Variabel X1 Return On Asset terhadap harga saham menunjukan nilai thitung sebesar 2.122 dengan nilai signifikansi sebesar 0.078 dengan demikian dapat disimpulkan bahwa secara Return On Asset tidak berpengaruh signifikan terhadap Capital Adequacy Ratio. Selanjutnya hasil uji t antara X2 Non Performing Loan terhadap harga saham menunjukan nilai $\mathrm{t}$ sebesar 5.058 dengan nilai signifikansi sebesar 0.002. Dengan demikian dapat disimpulkan bahwa Non Performing Loan berpengaruh signifikan terhadap Capital Adequacy Ratio.

\section{PEMBAHASAN}

Return On Asset salah satu jenis rasio profitabilitas yang mampu menilai kemampuan perusahaan dalam hal memperoleh laba dari aktiva yang digunakan. ROA akan menilai kemampuan perusahaan berdasarkan penghasilan keuntungan masa lampau agar bisa dimanfaatkan pada masa atau periode selanjutnya oleh Bank Mega Hasil uji t antara Variabel X1 Return On Asset terhadap harga saham menunjukan nilai thitung sebesar 2.122 dengan nilai signifikansi sebesar 0.078 dengan demikian dapat disimpulkan bahwa secara Return On Asset tidak berpengaruh signifikan terhadap Capital Adequacy Ratio.

NPL (Non Performing Loan) adalah salah satu indikator kesehatan aset suatu bank. Indikator tersebut dapat berupa rasio keuangan pokok yang mampu memberikan informasi penilaian atas kondisi permodalan, rentabilitas, risiko kredit, risiko pasar, serta likuiditas. NPL yang biasa digunakan adalah NPL neto, yakni NPL yang telah disesuaikan. Penilaian kualitas aset sendiri merupakan penilaian terhadap kondisi aset bank serta kecukupan manajemen risiko kredit. Hal tersebut berarti NPL merupakan indikasi tentang adanya masalah dalam bank tersebut, yang apabila tidak segera diatasi, maka akan membawa dampak buruk bagi bank itu sendiri. hasil uji t antara X2 Non Performing Loan terhadap harga saham menunjukan nilai t sebesar 5.058 dengan nilai signifikansi sebesar 0.002 . Dengan demikian dapat disimpulkan bahwa Non Performing Loan berpengaruh signifikan terhadap Capital Adequacy Ratio.

Dari uji Anova (Analysis of Varians) pada tabel 4.9 Dapat dilihat F sebesar 15.287 dengan nilai signfikan sebesar 0.004 Dengan demikian dapat dikatakan bahwa Return on Asset dan Non Performing Loan secara bersama-sama berpengaruh signifikan terhadap Capital Adequacy Ratio. 


\section{SIMPULAN}

Variabel Return on Asset dan Non Performing Loan Bank Mega Tbk periode 2010-2018 memiliki hubungan positif dan signifikan terhadap Capital Adequacy Ratio. Hal ini berarti Bank Mega Tbk, memiliki tingkat profitabilitas dan pasar yang tinggi akan berpengaruh terhadap harga saham. Bank Mega Tbk dengan Capital Adequacy Ratio yang tinggi menunjukkan bahwa nilai perusahaan tersebut mengalami peningkatan. Dengan demikian investor akan tertarik untuk berinvestasi pada perusahaan tersebut karena akan menyebabkan harga saham perusahaan yang bersangkutan cenderung meningkat.

\section{PENGHARGAAN}

Ucapan terima kasih disampaikan kepada seluruh pihak yang telah membantu penyelesaian penelitian ini.

\section{DAFTAR PUSTAKA}

Agustiningrum, R. (2013). Analisis Pengaruh CAR, NPL, dan LOAN TO DEPOSIT RATIO Terhadap Profitabilitas pada Perusahaan Perbankan.

Al Choir, F. (2012). Teori dan aplikasi Statistika 2. Tangerang Selatan: CV. Asmoro Mediatama.

Algifari. (2015). Analisis Regresi untuk Bisnis dan Ekonomi. Yogyakarta: BPFE.

Haryati, R. E. (2016). Pengaruh Leverage, Size, NPL, BOPO Dan LOAN TO DEPOSIT RATIO Terhadap Kinerja Keuangan Bank (Studi Pada Bank Umum Konvensional Yang Terdaftar Di Bursa Efek Indonesia Periode 2010-2014). Diponegoro Journal of Managemen.

Kasmir. (2003). Bank Dan Lembaga Keuangan lainnya. Jakarta: PT Raja Grafindo Persada.

Lestari, I. D. (2014). Analisis Pengaruh Rasio CAR, BOPO, dan LOAN TO DEPOSIT RATIO Terhadap Kinerja Keuangan Perbankan Yang Terdaftar Di Bursa Efek Indonesia Tahun 20082012. Jurnal Akuntansi. ISBN: 978-602-70429-2-6.

Malholta. (2015). Analisis Regresi untuk Bisnis dan Ekonomi. Yogyakarta: BPFE.

Nadia, S. (2010). Analisis Faktor-faktor yang memengaruhi Likuiditas Bank Syariah (Studi
Kasus Bank Syariah Mandiri). Skripsi. UIN Syarif Hidayahtullah.

Nusantara, A. B. (2009.). Analisis Pengaruh NPL, CAR, LOAN TO DEPOSIT RATIO, DAN BOPO Terhadap Profitabilitas Bank (Perbandingan Bank Umum Go Publik dan Bank Umum Non Go Publik di Indonesia Periode Tahun 2005-2007). Masters thesis Universitas Diponegoro.

Sabir, M., Ali. M. M \& Habbe. A. H. (2012). Pengaruh Rasio Kesehatan Bank Terhadap Kinerja Keuangan Bank Umum Syariah dan Bank Konvensional di Indonesia. Jurnal Analisis, 1(1): 79-86. ISSN: 2303-1001.

Soeroto. (2008). Metode Penelitian Untuk Ekonomi dan Bisnis. Yogyakarta.

Sudiyatno, B. Dan Suroso, J. (2010). Analisis Pengaruh Dana pihak ketiga, Bopo, Car Dan Loan to deposit ratio Terhadap Kinerja Keuangan Pada Sektor Perbankan Yang Go PublicDi Bursa Efek Indonesia (Bei) (Periode 20052008). Dinamika Keuangan dan Perbanka, 2(2) :125-137.

Sudiyatno, B. (2010). Analisis Pengaruh Dana Pihak Ketiga, BOPO, CAR, dan LOAN TO DEPOSIT RATIO Terhadap Kinerja Keuangan Pada Sektor Perbankan Yang Go Public Di Bursa Efek Indonesia (Bei) (Periode 20052008). Jurnal Dinamika Keuangan dan Perbankan, 2(2): 125137. ISSN : 1979-4878.

Sukma, Y. L. (2013). Pengaruh Dana Pihak Ketiga, Kecukupan Modal dan Risiko Kredit Terhadap Profitabilitas (Perusahaan Perbankan Yang Terdaftar Di BEI). Jurnal Akuntansi Keuangan, 14(1): 1.

Syafrida, F. N. (2015). Analisis Penerapan Tax Amnesty di Indonesia dalam Rangka Meningkatkan Penerimaan Negara pada Sektor Perpajakan. Jurnal Ilmiah Universitas Bakri, 3(3): 8 .

Tambunan, R. (2015). Mengupas Sunset Policy \& Tax Amnesty, Senjata Kejar Target Pajak. http://bisnis.liputan6.com/read/2217599/ mengupas-sunset-policy-amptax-amnestysenjata-kejar-target-pajak. Diakses 10 Oktober 2016.

Rose. P.S. and Hudgins. S.C. (2009). Bank Mana-gement \& Financial Services (8th ed.), New York: McGraw-Hill. 